Technische

Universität

Berlin

Jakub Galuszka

\title{
Transcending path dependencies: Why the study of post-socialist cities needs to capitalise on the discussion on urbanisation in the South (and vice
} versa)

Open Access via institutional repository of Technische Universität Berlin

\section{Document type}

Journal article | Accepted version

(i. e. final author-created version that incorporates referee comments and is the version accepted for publication; also known as: Author's Accepted Manuscript (AAM), Final Draft, Postprint)

This version is available at

https://doi.org/10.14279/depositonce-12503

\section{Citation details}

Galuszka, J. (2021). Transcending path dependencies: Why the study of post-socialist cities needs to capitalise on the discussion on urbanisation in the South (and vice versa). In Urban Studies (p.

004209802110471). SAGE Publications. https://doi.org/10.1177/00420980211047182.

\section{Terms of use}

This work is protected by copyright and/or related rights. You are free to use this work in any way permitted by the copyright and related rights legislation that applies to your usage. For other uses, you must obtain permission from the rights-holder(s). 


\title{
Transcending path dependencies - why the study of 'post-socialist' cities needs to capitalise on the discussion on urbanisation in the South (and vice-versa)
}

\begin{abstract}
Recently the theoretical relevance and utility of the regionalised notion of post-socialist cities have been questioned. The ensuing debate has resulted in several positions, including suggestions to drop the term entirely or to create a distinctive narrative based on the concept of a Global East, in order to position the knowledge as equal vis. a vis. discourses originating from Western power centres. This article responds to this call through efforts to transcend the dominant frames of research on post-socialist cities. However, I argue that the first step in overcoming the subaltern positioning of local knowledge is to refocus attention on previously marginalised urban phenomena, and to link the post-socialist research agenda to existing empowering discourses. The importance of creating linkages with the research originating from the South, and the potential for such joint engagements to contribute to global theorymaking are discussed in the context of the study of urban informality.
\end{abstract}

\section{Introduction}

One of the most influential contemporary events with relevance to planning and urban studies - the Habitat III conference - was held in Quito in October 2016. It provided an opportunity for a global community of practitioners and researchers to discuss the challenges faced by the contemporary cities and launch the New Urban Agenda. The participation in the event was, however, not as international as one might expect. The 'post-socialist' contexts were scarcely represented, particularly when it came to academic and non-governmental organisations. A quick glance at the side events reveals that out of over 200 events only two had a lead organisation based in a post-Soviet or CEE country. Only four events were explicitly concerned with development issues in these contexts. This is hardly any news - the absence of post-socialist contexts from international discussions is well acknowledged by now (Müller, 2021) and the core reasons for this detachment have been observed within the scholarship on post-socialist cities.

Specifically, the field has been criticised for its utilization of limiting spatiotemporal frames (Tuvikene, 2016), inward-looking orientation, and limited connection to global theory-making (Ferenčuhová, 2012). The ensuing debate has resulted in several positions. These include the 
proposed de-territorialisation of the notion of 'post-socialism' (Tuvikene, 2016; Wiest, 2012); the questioning of whether the notion has any contemporary relevance at all (Ferenčuhová, 2012; Gentile, 2018; Tsenkova, 2014) and arguments in favour of creating distinctive narratives, such as those of the 'Global East' (Chan et al., 2018; Müller, 2020; Trubina et al, 2020) or simply reflecting on the ordinariness of local cities (Gentlie, 2018).

Building on these lines of thought, this article attempts to transcend the dominant analytical frameworks of research on $\mathrm{CEE}$ and post-socialist cities towards a stronger contribution to global theory making and presence in international discussion on urban development. I suggest here that engagement with the debate on urbanisation in the South is both a powerful heuristic device and a pragmatic measure that may help us come closer to the outlined goal. This assumption stems from the fact that, for decades, both contexts (or what we could rather call 'epistemic constructs' ${ }^{\mathrm{i}}$ ) were positioned at the backstage of international urban studies. However, with a specific focus on decoloniality embedded in efforts of looking for alternatives to Western modernity (Hanchard, 1999), disentanglement from best-practice solutions (Watson, 2009), and recognition of ordinary everyday (Bayat, 2000) and informal practices (Roy, 2005) as an own logic of development, conceptualisations from the South have been achieved to influence global circuits of theory making. Taking clue from this approach, I argue that the first step towards overcoming the subaltern positioning of local knowledge in 'post-socialist' contexts is to refocus attention on previously marginalised local urban phenomena, and contextualise this theoretical debate via reflection on the state of planning practice. I argue that this approach is an essential step in substantiating any new discourses that wish to make their own true contribution (Trubina, 2020) and a move towards creating unexpected research coalitions, which may further complicate stereotypical divisions across the North, South, and East.

This exercise requires taking a step back to understand how the strong experience of marginality has been reworked in both the South and the East. This is, naturally, a risky endeavour with no ambition for universal generalisation (after all, each of the epistemic territories of the North, South, and East is an endless combination of urban realities). However, following the methodological outlook on experiencing the cites elsewhere (Robinson, 2016), I wish to reflect on an approach that enables breaking path dependencies in knowledge creation and taking a constructive stance on unique local phenomena. While taking a critical stance in discussing some of the main urban development trends and transitioning efforts post-1989, the purpose of the article is not to systematically review the impacts of these solutions, nor provide a 'judgement' on their positive or negative impact. In 
fact, many of those efforts have had clear benefits, with numerous primary cities in the CEE and post-soviet context being more liveable nowadays than before. The purpose of the article is rather to scrutinise the ways in which some research and planning agendas became marginalised as issues of secondary relevance in mainstream research on 'post-socialist cities' and to propose an approach to revisit these issues.

Considering multiply potential layers of analysis of marginalised areas in theory creation, I will concentrate mainly on informality in urban development as one of the most prominent theoretical contribution from the South, but also a phenomenon which is pervasive across post-socialist contexts. Beyond its analytical value for research on governance, agency, sovereignty and power (Haid and Hilbrandt, 2019; Banks et al., 2019; Polese et al., 2016) - it enables the possibility of entering into policy and scientific discourses regardless of the regional or academic niche (McFarlane, 2012; Watson, 2009). While traditionally linked with the discussion on urbanisation in the South, the validity of this approach has also been tested in Europe, the United States (Lombard, 2019; Potts, 2020), and across various contexts (including the post-socialist one) (Hilbrand, et al. 2017).

The paper is structured as follows. First, I review the positioning of urban informality as a theme across the South, East, and North, with an attention to knowledge flows within planning and urban studies. Second, after establishing the status quo, I take a step back to present practical examples of how some developmental and research agendas were selectively mainstreamed while others were marginalised. More precisely, in the sub-section 'planning practice and perceptions of development', I scrutinise two intertwined processes, which, I argue, have impacted this status: the uncritical and selective replication of planning trends from the power centres, as well as the process of orientalisation and dismantling urban informality. While concentrating on examples from CEE, I juxtapose these with an insight from related phenomena and planning responses in the South. The paper finalises by linking back to the theory and summarising the kind of learning, in terms of heuristics, analytical, and practical approaches, from the South that may be informative for academia in the East and vice-versa. This encompasses a proposal on potential areas of interest within the study of 'marginalised urban phenomena'.

State of the art: Informality research in urban studies and the global circulation of knowledge 
The phenomena that I utilise to illustrate the issue in question relates to the notion of informality (or the informality-formality continuum) as a driving force of urbanisation processes and one of the 'themes' relevant for theory creation beyond the hegemonic AngloAmerican centres of knowledge (Watson, 2008; Roy, 2009).

The term has been used across multiply fields. Historically, it gained momentum in economic discourse (Hart, 1973), where 'informal economy' was discussed as a creative manner of urban population to sustain their needs in a situation of poverty. It was strongly linked with the phenomenon of illegality, with some of the interpretations reinforcing informality as an issue of the 'developing world' (Boanada-Fuchs and Boanada-Fuchs, 2018). Although the idea of engaging with informality resonates in the planning and urban studies discourse within self-help housing solutions (Turner, 1977) or flexible tenure (Payne et al., 2009), the term has only gradually sunk into the developmental literature. Many of its interpretations pushed for the recognition of formalisation as synonymous with development and reinforced various dichotomies in the understanding of informality. For instance, a divide has been observed within spatial categorisation ('slum' vs. the formal city), organisational form (rules and regulations vs. lack of organisation) (McFarlane and Waibel, 2012). This simplicity in understanding urban informalities and the associated vision of modernity raised concerns about reviving colonial hierarchies (Varley, 2013).

A thorough reconceptualisation of the concept followed in connection with a broader turn in Southern urban and planning studies. While vast in its scope and contextual variations, a connecting factor of these contributions was the outlook on subaltern and everyday practices of ordinary population (Bayat 2004; Simone, 2004; Pieterse, 2008; Roy, 2009; Robinson 2013). Informality was positioned in this discussion as an urban logic and a process of structuration determining forms of institutional and individual relationships in an urban realm (Roy and AlSayyad, 2004) and an urban practice (McFarlane, 2012), where issues of power, resistance, and sovereignty are recognised. This debate entered into planning education (Odendaal, 2012) and urban practice, albeit the risk of romanticising upgrading approaches depending on informal solutions (Roy, 2005) and pushing service delivery obligations away from the state (Burgess, 1978) has been raised. Much of this theoretical framing was then traced back to the North, where a wider realisation of the scale of urban informality occurred.

The debate on informality in Eastern Europe has mainly been conducted outside of urban studies. It has concentrated on informality in relation to modernity as a form of social relation, economic practice, and a livelihood strategy (Misztal, 2000; Morris and Polese, 2013; Aliyev, 
2015). This perspective involved, for instance, the representation of potential positive impacts of informality as a way of getting by in times of economic hardship and retrieval of state offered social services (Polese et al., 2014). Not so differently from Simone's (2004) conceptualisation of 'people as infrastructure' or the notion of 'hustle economies' (Thieme, 2018), it reflected on mixed practices of exchanging favours and navigating the official system, often in a non-strictly legal manner (the practices so prevalent they gained a dedicated and commonly used names such as blat in Russian or załatwianie in Polish) (Ledeneva et al., 2018). However, as identified by Böröcz (2000), majority of local research on informality is characterised by a teleological-modernisationist approach, seeing these practices and economic activities as a synonym of backwardness and a characteristic of a 'second economy'. A more nuanced perspective visible in local scholarship, identified as a comparative-relativist approach, points out the existence of the same process in the West. The nature of criticism has therefore been similar to scholarship in the South, yet without tangible links forged between these contexts at this point.

Mainstream scholarship in urban studies, which is the main concern here, represents similar conceptual flows. The post 1989 transitions were described in a one-directional manner towards the achievement of Western-style 'healthy' market-based economic systems (Ferenčuhová, 2012, Wiest, 2012) and ignoring the multidimensional nature and often unachieved characteristic of this process (Gentile, 2018). This directionality is seen in some of the most influential conceptualisations of post-socialist transition, such as Sykora's and Bouzarovski's work (2012), which describe the institutional transformations as completed while positioning social practices and structures as 'still' retaining some socialist features (thus seeing the said practices as lagging behind the new formal setting). Big bulk of studies took this deterministic view on transformation, which 'reproduced the image of local urban studies as 'lagging behind' international research, being the 'object' rather than subject of studies, as well as lacking the ambition to contribute to urban theoretical debates' (Ferenčuhová, 2012: 65-66). Consequently, informality was not of major concern or was predominantly seen as an unwelcomed offset of a transformation process and post-communist deregulation. Some investigations which took place included a perspective on: street vending (Bromley, 2000; Rekhviashvili, 2015) adaptations of garages and basements for commercial purposes (Vasilevska et al., 2015), increase in self-built habitats and informal settlements in the former Yugoslavia, the Caucasus and Central Asia (Tsenkova, 2009), self-built extensions in large housing estates in Georgia (Bouzarovski et al., 2011; Salukvadze and Golubchikov, 2016), land invasions in Kyrgyzstan (Hatcher 2015) and the development of semi-regularised 
transport networks in cities such as Bishkek (Rekhviashvili and Sgibnev 2018). The most recent contributions engage with literature in the South more frequently and take a perspective on the issues of governance and power (Polese and Rekhviashvili, 2017). However, in spite of the similarity with some urban phenomena in the South (Grubbauer and Kusiak, 2012; Robinson, 2016b) and historic connectivity between these contexts (Stanek, 2020), efforts to link across the East and the South (and sometimes the North) are still nascent (see: Hilbrandt et al., 2017; Kębłowski and Rekhviashvili, 2020; Grashoff, 2020).

Unsurprisingly, more intensive collaborations and knowledge flows exist across the North and the South, where long-established channels of communication are in place (Trubina et al. 2020). It is, however, significant to note the reversed nature of these theoretical flows (Yiftachel, 2006) and the true capacity to inform Northern theoretical thought. The study of informality is recognised as highly relevant for the understanding of hidden dimensions of local urban development and the dismantling of the artificial dichotomies that permeate the urban development discourse (McFarlane, 2012; Acuto et al., 2019; Marx and Kelling, 2019). These include perspectives from Europe, North America, and Australia (Devlin, 2018; Durst and Wegmann, 2017; Lombard, 2019; Esposito and Chiodelli, 2020; Gurran et al., 2020).

What we are left with is a void of contributions emanating from 'post-socialist' contexts in spite of their liminal positioning (Müller, 2018; Rekhviashvili and Sgibnev, 2018; Sayin et al., 2020) as 'mediating sites of neocapitalism between the Global North and the South' (Polese et al. 2016: 181). In the following part of the paper, I will move on to discuss the main reasons for and practical manifestations of this dislocation.

\section{Planning practice and perceptions of development}

As trivial as it may sound, the fall of socialist regimes in CEE in the early 1990s brought a major change in the way local cities evolved. The formerly socialist countries almost immediately jumped to the category of transition economies, shifting towards capitalism and the establishment (initially at least) of liberal socio-political systems. This re-positioning was soon reflected in the academic debate. Issues such as growing socio-spatial polarisation, suburbanisation, ghettoization, weak institutions, and the role of private sector in shaping spatial structure of the cities (Kovács, 1999; Kok and Kovács, 1999; Sýkora and Bouzarovski 2012; Tammaru et al., 2015; Hirt, 2013) became the leitmotifs of post-socialist studies. This brought with it a thorough but selective framework for the investigation of urban phenomena with relatively little input from post-soviet states. Even though with time the debate has 
become increasingly contextualised and infused with cross-disciplinary perspectives, the postsocialist terminology remains in use to this day (Gentile, 2018). This one-directional understanding of urban development have also had profound effects on urban practice. I will discuss manifestations of this problematic through an insight into two interlinked processes replication of planning trends from power centres and dismantling of urban informality across selected contexts in the East and South.

\section{Uncritical and selective replication of planning trends from the power centres}

Probably the most reflective strains of the research, which recognised the impacts of the 'catching up with the West' process, was the cleansing of the semiotic landscape of city from the symbols of the communist period (Czepczyński, 2008) and the creation of new ones that fit with the imaginaries of the West. While typically still operating within a post-socialist framework, this type of analysis illustrates very well how the narratives of transitions affected local planning practices.

The most basic manifestation of this can be seen with the creation of mega projects andextravagant architecture celebrating modernity or historic imaginaries (Mojanchevska, 2020), and viewed 'as a quick fix in achieving a modernised and globalised image for the capital and, by implication, in linking the whole nation to the 'European civilisation' (Salukvadze and Golubchikov, 2016: 49). The spread of iconic buildings in CEE and the Caucasus, rather than being a manifestation solely of the ambition and power of specific city governments (often executed by the private sector), should also be understood as a manifestation of a broader policy focus guided by an uncritical and selective replication of planning trends from the power centres. This, in the same way as in various African cities (Watson, 2014), meant that broader systemic solutions were applied without reflecting on the fact that just because something works in one context (e.g. the West) does not necessarily mean it will succeed in another (Kunzmann, 2004).

Culture let regeneration, creation of iconic buildings with an intention of creating Bilbao effect and attracting creative classes into cities can be identified as one of such 'copy paste' planning approaches. This is an approach that, despite decades infiltrating urban planning thought across the globe (including CEE) (Boren and Young, 2016), has had at best only limited success, and more commonly either ambiguous effects or no effects at all (yet in each case cannibalising the public resources and international grants). 
The example of city of Łódź in Poland and the way its urban policies evolved over time illustrates this point well. The city suffered from the very hardest transformation after the fall of the USSR, becoming a classic example of a mono-functional, shrinking city. With its rich industrial heritage, the city emerged from its socialist past as a perfect laboratory for the implementation of mainstream solutions originating in the UK (Zysiak, 2014). It took around 20 years for city authorities to shift away from a focus on creative classes, culture-led development, iconic buildings and the Bilbao effect, to acceptance of the need to truly commit to the regeneration of the seriously deteriorating inner city characterised by near 'slum'-like conditions and social deprivation issues (Warzywoda-Kruszynska and Jankowski, 2013). Today the balance between different urban regeneration approaches is arguably more reflective of sustainability and equity principles. However, the earlier urban renewal efforts was a typical example of post-socialist city administrations' desire to distance themselves from the socialist period, and to underscore their belonging to Europe through the reference to 'golden pre-socialist times' (Young and Kaczmarek, 2008).

City authorities' selectiveness in prioritising specific aspects of the urban development process remains a key point here. Through tracing the phenomenon of 'zombie-socialism' (Chelcea and Druţă, 2016) (meaning the orthodox separation from whatever approaches were considered as 'socialist') it becomes clearer why Western-originated solutions, occurring in conjunction with the roll-out of neo-liberalism, were treated as a mantra in local urban development practice (Benda-Beckmann et al., 2009). Ironically, this orientation led to the dismantling of many solutions that were gaining popularity at the same time in the West but did not fit into the imagined, ideal model of a Western city. This includes, for example, the growth in co-housing and rental housing, which were largely dismantled in the CEE after the 1990s (Coudroy de Lille, 2015) and which have started to be reintroduced across the region only recently. In these cases, ideologies involving beliefs in the need to create market economies and redress the harms of the past (Lux and Mikeszova, 2012) were key factors in making decisions about cities' development trajectories. The same approach left its mark in contexts where self-made settlements were more common and private ownership was positioned as the principal form of land and housing rights. Beyond the CEE context, this was supported by the roll-out of an enabling approach promoted by the World Bank, as well as influential economist Hernando De Soto, whose works advocated for the transfer of property titles to the urban poor as a way for them to accumulate capital and lift them out of poverty. However, by the time the roll-out of the approach started in countries like Kyrgyzstan (Hatcher, 2015), Albania and the former Yugoslavia (Tsenkova, 2009), it was strongly 
criticised as an approach that failed to reach its objectives (Gilbert, 2002; Payne et al., 2009). Furthermore, a rich portfolio of alternative tenure solutions that better reflected the ways the urban poor organised land ownership matters, based on experiences from Latin America was documented by this time. Nevertheless, in contrast to the clear rallying of parts of the academic sector in 'the South' against simplistic understanding of land ownership in informal settlements represented by De Soto's views (Roy, 2005), the approach either faced limited criticism in the post-socialist context, or such criticisms were unable to garner attention beyond the very local realm.

In the meantime, across many parts of the world alternative formats for land access or community ownership in informal contexts had been circulated via the work of international grass-roots movements. However, a glimpse at the coverage of two major housing networks in the world, the Habitat International Coalition (HIC) and the Asian Coalition of Housing Rights (ACHR), shows a vast gap in CEE and post-soviet contexts (except of efforts of the ACHR in Mongolia). HIC has a substantial presence in nearly all regions except CEE, the Caucasus, Central Asia and Australia, while the ACHR has representation across most of Asia, except for in Central Asia and the Caucasus. The case of the ACHR is particularly interesting, considering the network's failed efforts to establish a presence in Kazakhstan, and its ability to launch activities in Vietnam and Mongolia - countries that share a number of historic commonalities with post-Soviet states. As such the local housing struggles in countries like Kazakhstan and Kyrgyzstan (Isabaeva, 2018), quite similar in their nature to international experiences, are not incorporated in global rights to the housing discourse.

To sum up, for many critical scholars, the ease with which the Western model of transformation was applied is seen as something akin to a new colonial dependency on external influences, replacing what others considered to be the colonial influence of former Russian and then Soviet empires (Stenning and Hörschelmann 2008; Miłosz, 1953, Lisiak, 2010). The application of this one-dimensional planning approach was, of course, not the responsibility of researchers operating with the post-socialist terminology, many of whom thoroughly documented the issues of growing socio-spatial segregation, gentrification and displacement. However, going back to the argument of Ferenčuhová (2012), the post-socialist discourse, as much as it produced worthwhile research, was often done without acknowledgement or reflection on the fact that the framework of analysis in itself legitimises the rightfulness of the transition towards the Western model.

I would like to conclude this part of the article by referring to a question posed by 
Sonia Hirt (2013: 36): ‘today's East-Central European cities resemble Western cities much more so than they did a quarter of a century ago. Have they then become capitalist? Is there still a 'post-socialist city' (assuming there ever was one) or has it melted into a broader category?'. Although the observation that CEE cities more and more resemble those of Western Europe is clearly valid, the argument I put forward in the following part of this article is that it is in fact impossible to know what cities in CEE are nowadays if we keep on describing them solely in terms of how they compare to Western cities.

\section{CEE - orientalisation and dismantling of urban informality}

The growing body of literature that recognises issues of power, informality and its multidimensional potential as a site of critical analysis (Banks et al., 2019) remains at odds with the more conventional view on informality held by planning practice and parts of academic sector. In this conservative perspective informality is criminalised and orientalised as foreign or transitional' phenomena (Polese and Rekhviashvili, 2017). Consequently, within the analytical focus of post-socialist urban studies, phenomena such as self-built extensions within large housing estates, either for living or commerce, were seen as resulting primarily from the absence of rules or loosening of governmental control (Vasilevska et al., 2015). Even in the rare situation where they were allowed by governments, as in the case of Georgia, these forms of development were eventually stigmatised by local experts as a 'menace to the development of the city' (Bouzarovski et al., 2011: 2701) and eventually forbidden. Similarly, informal settlements were most often identified as a symptom of a state's failure to organise their regulatory mechanisms fast enough. From the government's perspective, their existence was considered to be normatively bad and as something that should be no more than 'tolerated'. In this type of cases the mainstream research approach suffered from the same deficiencies as found in the Euro-American academic tradition; namely, of thinking of informality as the absence of formality (Banks et al., 2019), thereby reinforcing the dichotomy between the two. Consequently, in spite of the inherent complexities in the relations between them, this simplistic understanding of the formality-informality continuum was manifested in urban development policy and practice.

The contestation of informality as 'foreign' forms of development in CEE was clearly linked to the prevalence of 'idealised' vision of Western city in official policy making and urban development debate. A striking manifestation of a similar trend resonates in the conference 'Is Warsaw Becoming a City of the Third World?', which took place at the University of Warsaw 
in 2006 (and was still referred to by local press in 2020). One of the seminal post-conference articles described the following issues in the city:

'Shabby shacks, the exotic food stalls and sex shops are located on the main streets of the city: Marszałkowska and Al. Jerozolimskich. Next to it, on Próżna street, stand the ruins of allegedly historic buildings, which cannot be torn down nor be rebuilt, because the conservationist does not allow it (...) In the whole city centre the illegal street vendors sell (typically smuggled) clothing, household items and illegal CDs. For years the city authorities were unable to handle this compromising phenomenon. The city centre is dirty and the street sweepers, used for cleaning streets in Paris and London, are not used in the Polish capital anymore. Sloppiness, dirt and disorder are typical features of a 'Third World City', (Jałowiecki 2006: 51).

While these 'aesthetics of chaos' (Kusiak, 2012) may have indeed complicated the formal development processes in some instances, the issue remains of how such a onedimensional understanding of complex urban processes may have shaped the academic perception and planning response to informality. An insight into the area of the city (Plac Defilad) referred in the quoted article illustrates these complexities. After the fall of the Soviet bloc and change in the political regime in 1989, a portion of a huge area surrounding the monumental soviet-styled Palace of Culture and Science started to be used as a semitemporary market space. This space was spontaneously claimed by unsolicited traders who initially erected their temporary stalls without permission or a fee. During peak periods there were around 2000 people trading in the area. Due to difficulties in managing the space, the city gave a number of concessions to private companies who collected the tenancy fees from traders and dealt with the site management. In the 1990s the market experienced a back-andforth story of attempted relocation, resistance and partial formalisation through construction of more permanent structures (Bartoszewicz, 2013). In 2006 the city's authorities decided to reclaim the space in an attempt to beautify the area. This process led to street riots, fights with the police, and the blockage of the city's main street. After intense and forceful action involving police intervention the traders were finally moved to another location. However, this operation, did not result in development in line with the proposed policy 'remedies' such as the promotion of star architecture or attracting the creative class to the city (Jałowiecki, 2006).

During the last three decades since 1989 the city has attempted to develop Plac Defilad several times, based on ideas ranging from densification through reconstruction of the pre-war 
urban grid, to filling in the vacant space with skyscrapers (Górczynska et al., 2019). The first development idea clearly reflected the nostalgic attempts to forge connections to pre-war traditions of the city, while also being related to the controversial idea of removing the iconic Palace of Science and Culture, which was seen by many as an example of imposed heritage of the Soviet Union. The second reflected a 'global city aspirations', curiously resembling urban fantasies from Africa (Watson, 2014) or the mega projects of Asian cities. In addition, the efforts to redevelop the space also included a couple of competitions for the design of the Modern Art Museum (Kusiak, 2018), the creation of new public spaces, and the selling of land to private investors. Such attempts at redeveloping the urban space have largely failed, due to the inability to merge different land titles in the area as a result of restitution law, which acknowledged the pre II World-war ownership structure of the city. The law was misused through speculation with these land titles by syndicates of investors, sometimes in informal partnership with municipal workers (Kusiak, 2019). Finally as of date, only the said museum started to be constructed in 2019 and the temporary trading or consumption spaces keep on popping up in the area.

The juxtaposition of these two seemingly separate processes - firstly, the fight over the use of space by traders; and secondly, the restitution issues - illustrates informality as one of the key framing factors of the central location of the city and its role in regulating structural power relations at various levels (Polese et al., 2016:17). The opportunistic move to relocate traders highlights the municipality's commitment to modernise a key space in the city and rid itself of the kind 'informality' deemed unfit for the capital of a European country. In parallel, similarly informal activities were conducted at an administrative level to secure financial gains for groups involved in speculative activities. The ability of specific groups to employ legal language to push for their own interests (Kusiak, 2019) represents the process of how advantaged groups selectively utilise informal solutions (Banks et al., 2019), while trying at the same time to evict the informality manifested in the imaginaries of backwardness.

Paradoxically, and in a similar way to the process of othering of Eastern Europe by power centres in the Western Europe (Kuus, 2004), the discussed example illustrates the common tendency to distinguish CEE from 'the Third World'. At the same time, the way informality is treated directly replicates the past (and often current) policy responses from the South where 'modernity continues to be associated with the formalisation of economic and residency status, while informality is designated as a sign of 'backwardness' and of secondary social status' (Banks et al., 2019: 230) - an outlook that was strongly inculcated by the historical experience of colonialisation. Parallels with similar processes of dismantling street 
vending in Sofia (Venkov, 2018) or Tbilisi (Rekhviashvili, 2015; Polese et al., 2016) highlight the comparative value of the study of informality in post-socialist cities and beyond. For instance, the process of the dismantling of informality and its relations to urban governance and the modernisation process were thoroughly discussed in the case of cities such as Johannesburg. The biggest metropolis of Southern Africa, chasing the image of a world-class city (Sihlongonyane, 2015), engaged in a series of modernisation-inspired initiatives, including the eviction in 2013 of an estimated 6000-7000 informal traders through 'Operation Clean Sweep' (Rogerson, 2016). In response, the local academic sector did not limit itself to just researching the phenomena; instead, despite having limited capacities to impact the process, it provided a platform for the engagement between traders' organisations and the city in the post-removal period (Benit-Gbaffou, 2016). This approach contrasts sharply with the heuristic device employed in Warsaw, in which the aforementioned conference ('Is Warsaw Becoming a City of the Third World ?') academics advocated for the dismantling of informality and adaptation of copy-paste solutions from the West. The former engaged with the subaltern and worked towards localising the practice of urban development; the latter with the agendas of power holders and globalizing this practice.

\section{Marginalised urban phenomena and learning across the South and the East—a way forward}

As illustrated in the preceding subsection, the flows of knowledge circulation tend to omit post-socialist contexts. As much as the issue of inner orientation is at the core of the problem (Gentlie, 2018), further externalities make it even more challenging to break through with a novel local contribution at an international level. Post-socialist research's double exclusion from global discourses is a major issue: its position outside mainstream urban studies, as well as its 'insignificant role in recent post-colonial critiques of this field' (Tuvikene, 2016: 133). Similarly, from the perspective of Western academia, local research is typically 'fitted' into existing discourses. For instance the original analysis practices, such as food-self provisioning, are likely to be seen as an expression of 'culture of shortage' or 'economy of scarcity' (Jehlička, 2021). Lastly, the language exclusion is a major concern (Müller, 2021b), although the same problem may be raised regarding works on informality and other urban phenomena in Latin America (Varley, 2013), not to mention francophone Africa.

Is there, therefore, a way forward to facing these internal and external limitations? The quick outlook at planning practice in the review of the selective replication of planning trends from 
the power centres and the orientalising and dismantling of urban informality, direct at two key points of this paper and anchors we could use for such an operation. First, the overarching frame of development in which peripheries desperately want to (or have to) replicate the strategies of the power centres is a powerful condition impacting local patterns of development across both the South and the East. This condition, more than any other predicament, can be a strong motivator for finding common ground in new theorisations, methodological approaches, and urban experimentation. Second, shared phenomena such as various forms of informality do occur across the East and the South.

The first point brings me back to the initial argument of this paper. If any inspiration from the South may be pointed at, it is the recognition of the need to 'deconstruct what we think we know, disrupting norms about what is familiar and what is strange' (Sheppard et al., 2013: 895) or, as put by Gentile (2018: 10), 'dropping the implicit assumption of Western normality, and thus of the normality and applicability of Western-made theories, we may be able to unleash vast untapped intellectual resources'. If the experience of peripherality across the South and the East can be treated as a commonality, then the Southern take on the study of informality (or other marginalised phenomena) can help us bring to the table shades of local urbanity in the East as well. This leads me to the second point: looking at similar phenomena and engaging in planning practice as a vehicle for the knowledge decentring process. While the vast diversity of contexts across the South and the East may position this task as challenging, I argue after Caldeira Caldeira (2017: 4) that 'peripheral urbanisation is remarkably pervasive, occurring in many cities of the south, regardless of their different histories of urbanisation and political specificities'. One solution in facilitating this process in real terms is to look across phenomena identified by Southern scholars as containers of peripheral practices, since the 'Southern questions can well be asked from the peripheries of all cities, no matter where they are' (Bhan, 2019: 642). For instance, Bhan's categories for engagement between academia and practice means producing a common language of investigation and scrutinising processes such as: squatting, repair and consolidation. Although not all categories identified through these types of exercise may fit across all contexts in the East (just as they do not fit across all contexts in the South), they provide an opening for the initial engagement and testing of common areas of interest. A curious example of this may be found when we juxtapose the notion of repair from India (Bhan, 2019) with Sgibnev's (2015) investigation of the practice of 'remont' in the context of Tajikistan. Both render conceptual similarity and emerge as promising opportunities to enrich the vocabularies of practice from a non-anglophone perspective (Zhao, 2020). 
In other words, the benefit of learning from the South in post-socialist contexts means challenging the dominant modes of knowledge production with heuristic and methodological perspectives from the South (Point 1) and substantiating this approach through exploration of how similar 'marginalised' phenomena unfold and are tackled in urban practice, activism, and engaged academia across relevant contexts (Point 2). Engagements around planning practice may provide an opportunity to map relevant (dis)similarities of processes, work towards the development of joint vocabulary, as well as the portfolio of approaches for engaged academic practice and institutional development (with good examples such as African Centre for Cities, its master in 'Southern Urbanism' or African Urban Research Initiative implemented by universities across the continent).

However, it is crucial to bear in mind that the second point needs to be treated with caution and should gradually lead to the expansion of areas of enquiry developed in cooperation with the 'Southern' perspective. This ultimately means using heuristic and epistemological approaches (Point 1) to facilitate enquiry about one's own marginalised phenomena, including and extending the problematic of informality. Several examples illustrate such an approach. First, the discussed case of Warsaw documents and how street vending was dismantled in its core symbolic location. However, as suggested by Gonzalez (2019), the investigation of marginal marketplaces provides a different opportunity for theoretical contributions. Indeed, in Warsaw's own peripheries, undisturbed with the implementation of 'prestige planning', the pop-up and informal markets underwent completely different pathways than in its central locations. This marginal status was, in the first place, a condition for them to exist, but it also resulted in limited interest from the academic community. After gradual consolidation, these spaces became an appreciated element of district life-a phenomenon common across various Easter European contexts and often a crucial element of livelihood creation and affordable food provisioning (Shokalo, 2011; Humphrey and Skvirskaja, 2009). Consequently the outlook on 'own' peripheries would support recognition of home-grown solutions or various forms of hybridity that merge globalising ambitions with local needs in everyday life and policy development (Robinson, 2008). The trading spaces are just one possible example, whereas a wider portfolio of 'themes' needs to be considered and proposed by the wider academic community in various contexts across the East.

Second, the approach to self-marginality may also include reflection on past phenomena, which, in line with modernisation discourses, have been contested in official urban policies and eventually eradicated or pushed to grey spheres of urban development. An example of this can be the deregulation of the early 1990s, which, in a truly paradoxical manner, can now 
be seen as a laboratory of self-made transitions and ways of navigating formalisation beyond the South. The processes, which took place before formalisation, and arguably some hidden innovative approaches towards formalisation, may become relevant now in completely different contexts (see deregulation approach and housing extensions issue in English housing market (Lombard, 2019; Ferm et al., 2020) or proposed deregulation in housing policy in Poland). This perspective provides a different set of opportunities than self-made transitions from Africa or Asia, which typically occur from scratch rather than in ready-made material frames.

Third, the reflexivity towards self-marginality means critically revisiting dominant lines of enquiry in specific thematic niches popular in post-socialist contexts and revaluating the way these were framed. For instance the numerous quantitative studies documenting decreasing socio-economic status in large housing estates from pre-fabricated panels in CEE used the development patterns of Western European estates as a benchmark of a possible future. In other words, the expectation of local cities becoming more and more like Western European cities (Hirt, 2013) positioned local estates at risk of declining into 'slums' (Enyedi, 1998). However, in spite of the documented decreasing or fluctuating status, many estates continue to be attractive for various groups of users, and efficient upgrading and management solutions are being deployed to increase the liveability and quality of these spaces. Consequently, a deep qualitative study documenting these processes, rather than being labelled merely as 'divergent pathways of development' (Temelová et al., 2011), might hold more interesting potential for reversed 'benchmarking' (or reversed best-practice solutions) between Eastern and West Europe. Similarly, in the context of increased interest in the creation of massive low-income multi-storey housing in cities such as Addis Ababa or Delhi, it is not hard to imagine that the exchange of expertise and solutions between the East and the South can be truly beneficial for these developments.

\section{Conclusions}

The recent debate on post-socialist cities has made significant advances in understanding their own marginalities within international urban studies. This came with the recognition of the need to disentangle from Western assumptions on urban modernity as a means of breaking path dependencies in theory creation. The proposal included de-territorialising post-socialism as a concept (Tuvikene, 2016), looking at these cities as ordinary ones (Gentile, 2018) or new discourses, such as the Global East (Müller, 2020). 
In this article, I argue that it is not enough to stop at this. Turning to the ordinariness of cities, although well justified as an analytical step, will not automatically make marginal (or even major) towns of deep Asia or Ukraine interesting to the international research community. Framing new discourse, such as the Global East, as much as empowering in attempts, will always hold the risk of simplistically replacing the old discourse ${ }^{\mathrm{ii}}$, if not substantiated with a practical approach for moving beyond the existing detachment. Considering the leading academic and funding institutions will not suddenly shift long-term collaborations (Tuvikene, 2016) to obscure Eastern contexts, I argue that a way forward lies in linking with the existing empowering discourses. It involves benefiting from a decolonial approach, which helped selected theorisations from the South reach international recognition. This operation requires careful attention and a balance between the benefits and risks involved. What comes first is the recognition that the historical connectivity with Western Europe as much as intuitively 'felt' across CEE and big bits of Eurasia should not discard the reflexivity of shared experiences with other contexts. This reflexivity is challenging because, as I demonstrated in the review of some planning trends in CEE, the phenomena that are similar across both East and South tend to be labelled in the former as 'foreign' forms of development. For instance the informality, rather than being treated as a relevant resource, is seen as a risk factor in chasing the imagined ideal model of a Western city. This very outlook epitomises the same framing condition as in multiple cities in the South: the persistence of external imaginaries on how a proper city should look and, in some cases, own exaggerations of these imaginaries (as shown in an example of dismantling rental housing in CEE). This similarity provides a strong first basis for learning from the South in terms of shifting attention to local modes of development and taking the active role of academia in mainstreaming these nuanced approaches.

Building on these foundations, I suggest working towards new theoretical conceptualisation through careful review of what phenomena might have been overlooked so far in mainstream academic inquiry. Here again, the exchange between the East and the South comes handy. The recent debate on linking theory and practice in the South (Bhan, 2019) offers a good opening for such an engagement. Seeing how marginal practice unfolds itself across different contexts renders the possibility of a refined language of enquiry and a search for commonalities and differences that can then be forged into a platform of cooperation. The question of what 'appropriate' contexts for exchange may be is up for further scrutiny. Using the international legacies of post-socialism may be a starting point, but again, I suggest focusing on contemporary (marginal) practice and urban activism as a promising opening. 
The discussed examples of the dismantling of informality between Warsaw and Johannesburg or the notion of 'repair' and 'remont' in India and Tajikistan (Sgibnev, 2015) (in fact multiple of other post-socialist contexts) are as justifiable as any comparisons between urban transformations across CEE and Western Europe. Endless other connections may be further envisaged with the opening up of thematic horizons of mainstream enquiry.

With all the promising sides of this approach, it is crucial to be weary of overly idealising the 'Southern' theoretical conceptualisations, not to fall into the trap of uncritically replacing the dominance of old 'Western' discourse with the Southern one. I suggest that this risk can be avoided as long as the Southern approach is treated as a starting point and as a conceptual device for uncovering home-gown phenomena. A discussion on the way forward in this paper illustrates such three approaches, which hold the potential to inform theorisations and urban practice both in the South and the North.

To sum up, building real connections between 'marginalised' contexts that go beyond the basis of previous colonial relations, language, or convenience may be a meaningful mechanism for disrupting current flow of knowledge creation. Setting-up new, stronger research networks, engaging in joint studies, and establishing collaborative advocacy platforms around these themes, are essential steps that must be taken in order to challenge existing path-dependencies and build engaged academia. At the same time, new configurations of cooperation can help to bring to light a vast pool of knowledge relating to both failed and successful urban development approaches from CEE, the Caucasus and Central Asia - knowledge that has the potential to inform urban theory and practice beyond real or imagined geographic boundaries and self-imposed academic silos.

\section{References}

Acuto M, Dinardi C and Marx C (2019) Transcending (in) formal urbanism. Urban Studies 56(3): 475-487.

Aliyev H (2015) Post-Soviet informality: towards theory-building. International Journal of Sociology and Social Policy 35(3/4): 182-198.

Bartoszewicz D (2013) Plac Defilad 20 lat histori upadku centrum Warszawy. Gazeta Wyborcza 5 January, 2013.2 Available https://warszawa.wyborcza.pl/warszawa/1,34862,13139591,Plac_Defilad_20_lat_historii_u padku_centrum_Warszawy.html (accessed 25.09.2020) 
Banks N, Lombard M and Mitlin D (2019) Urban informality as a site of critical analysis. The Journal of Development Studies 56(2): 223-238

Bayat A (2000) From dangerous classes' to quiet rebels'. Politics of the urban subaltern in the Global South. International Sociology 15(3): 533-557.

Benda-Beckmann F, Benda-Beckmann K and Griffiths A (2009) Space and legal pluralism: an introduction. In: Benda-Beckmann F, Benda-Beckmann $\mathrm{K}$ and Griffiths $\mathrm{A}$ (eds) Spatializing Law. London: Routledge, pp.15-44.

Bhan G (2019) Notes on a Southern urban practice. Environment and Urbanization 31(2): 639-654.

Bénit-Gbaffou C (2016) Do street traders have the 'right to the city'? The politics of street trader organisations in inner city Johannesburg, post-Operation Clean Sweep. Third World Quarterly 37(6): 1102-1129.

Borén T and Young C (2016) Conceptual export and theory mobilities: exploring the reception and development of the "creative city thesis" in the post-socialist urban realm. Eurasian Geography and Economics 57(4-5): 588-606.

Boanada-Fuchs A and Boanada-Fuchs V (2018) Towards a taxonomic understanding of informality. International Development Planning Review 40(4): 397-421.

Böröcz J (2000) Informality rules. East European Politics and Societies 14(2): 348-380.

Bouzarovski S, Salukvadze J and Gentile M (2011) A socially resilient urban transition? The contested landscapes of apartment building extensions in two post-communist cities. Urban Studies 48(13): 2689-2714.

Bromley R (2000) Street vending and public policy: a global review. International Journal of Sociology and Social Policy 20(1/2): 1-28.

Burgess R (1978) Petty commodity housing or dweller control? A critique of John Turner's views on housing policy. World Development 6(9-10): 1105-1133.

Caldeira TP (2017) Peripheral urbanization: Autoconstruction, transversal logics, and politics in cities of the global south. Environment and Planning D: Society and Space 35(1): 3-20.

Chan KW, Gentile M, Kinossian N, Oakes T and Young C (2018) Editorial - theory generation, comparative analysis and bringing the "Global East" into play. Eurasian Geography and Economics 59(1): 1-6. 
Chelcea L and Druţă O (2016) Zombie socialism and the rise of neoliberalism in post-socialist Central and Eastern Europe. Eurasian Geography and Economics 57(4-5): 521-544.

Coudroy de Lille L (2015) Housing cooperatives in Poland. The origins of a deadlock. Urban Research \& Practice 8(1): 17-31.

Czepczyński M (2016) Cultural landscapes of post-socialist cities: representation of powers and needs. London/New York: Routledge.

Devlin RT (2018) Asking 'Third World questions' of First World informality: Using Southern theory to parse needs from desires in an analysis of informal urbanism of the global North. Planning Theory 17(4): 568-587.

Durst NJ and Wegmann J (2017) Informal housing in the United States. International Journal of Urban and Regional Research 41(2): 282-297.

Enyedi G (1998) Transformation in Central European postsocialist cities. In: Enyedi G (ed) Social Change and Urban Restructuring in Central Europe. Budapest: Akademiai Kiado,'pp. 9-34.

Esposito E and Chiodelli F (2020) Juggling the formal and the informal: The regulatory environment of the illegal access to public housing in Naples. Geoforum 113: 50-59.

Ferenčuhová S (2012) Cities and urban research in postsocialist Europe. In: Edensor T and Jayne M (eds) Urban Theory beyond the West: A World of Cities. London: Routledge, pp. 6574.

Ferm J, Clifford B, Canelas P and Livingstone N (2020) Emerging problematics of deregulating the urban: The case of permitted development in England. Urban Studies 0042098020936966.

Gilbert A (2002) On the mystery of capital and the myths of Hernando de Soto: what difference does legal title make? International Development Planning Review 24(1): 1-19.

Gentile M (2018) Three metals and the 'post-socialist city': reclaiming the peripheries of urban knowledge. International Journal of Urban and Regional Research 42(6): 1140-1151.

Gonzalez S (2020) Contested marketplaces: Retail spaces at the global urban margins. Progress in Human Geography 44(5): 877-897. 
Górczyńska M, Śleszyński P and Niedzielski AM (2019) Impact of property rights and ownership on the development of Warsaw's contemporary city centre. European Planning Studies 27(1): 160-180.

Grashoff U (ed) (2020) Comparative approaches to informal housing around the globe. London: UCL Press.

Grubbauer M and Kusiak J (2012) Post-Socialism and the Dynamics of Urban Change. In: Grubbauer M and Kusiak J (eds) Chasing Warsaw: Socio-material dynamics of urban change since 1990. Frankfurt/New York: Campus Verlag, pp.9-24.

Gurran N, Pill M and Maalsen S (2020) Hidden homes? Uncovering Sydney's informal housing market. Urban Studies 0042098020915822.

Hatcher C (2015) Globalising homeownership: Housing privatisation schemes and the private rental sector in post-socialist Bishkek, Kyrgyzstan. International Development Planning Review 37(4): 467-486.

Haid C and Hilbrandt H (2019) Urban informality and the state: geographical translations and conceptual alliances. International Journal of Urban and Regional Research 43(3): 551-562.

Hart K (1973) Informal income opportunities and urban employment in Ghana. The Journal of Modern African Studies 11(1): 61-89.

Hanchard M (1999) "Afro-moderni: temporali, politics, and the African diaspora." Public Culture 11(1): 245-268.

Hilbrandt H, Alves SN and Tuvikene T (2017) Writing across contexts: Urban informality and the state in Tallinn, Bafata and Berlin. International Journal of Urban and Regional Research 41(6): 946-961.

Hirt S (2013) Whatever happened to the (post) socialist city? Cities 32: S29-S38.

Humphrey C and Skvirskaja V (2009) Trading places: Post-socialist container markets and the city. Focaal 2009 (55): 61-73.

Isabaeva E (2020) Squatters and the socialist heritage: A comparison of informal settlements in Kyrgyzstan and Kazakhstan. In: Grashoff U (ed) Comparative approaches to informal housing around the globe. London: UCL Press, pp. 95-109. 
Jałowiecki B (2006) Is Warsaw becoming a city of the Third World? Studia Regionalne $i$ Lokalne 4: 48-60.

Jehlička P (2021) Eastern Europe and the geography of knowledge production: The case of the invisible gardener. Progress in Human Geography 0309132520987305.

Kębłowski W and Rekhviashvili L (2020) Moving in informal circles in the global North: An inquiry into the navettes in Brussels. Geoforum. https://doi.org/10.1016/j.geoforum.2020.08.014

Kok H and Kovács Z (1999) The process of suburbanization in the agglomeration of Budapest. Netherlands Journal of Housing and the Built Environment 14(2): 119-141.

Kovács Z (1999) Cities from state-socialism to global capitalism: an introduction. GeoJournal 49(1): 1-6.

Kunzmann K (2004) Culture, creativity and spatial planning. Town Planning Review 75(4): 383-404.

Kusiak J (2012) The cunning of chaos and its orders: A taxonomy of urban chaos in postsocialist Warsaw and beyond. In: Grubbauer M and Kusiak J (eds) Chasing Warsaw: Sociomaterial dynamics of urban change since 1990. Frankfurt/New York: Campus Verlag, pp. 291-321.

Kusiak J (2019) Rule of law and rules-lawyering: legal corruption and 'reprivatization business' in Warsaw. International Journal of Urban and Regional Research 43(3): 589-596.

Kuus M (2004) Europe's eastern expansion and the reinscription of otherness in East-Central Europe. Progress in Human Geography 28(4): 472-489.

Ledeneva A (ed) (2018) Global Encyclopaedia of Informality, Volume 2: Understanding Social and Cultural Complexity. London: UCL Press.

Lisiak AA (2010) Urban cultures in (post) colonial Central Europe. Purdue University Press. Lombard M (2019) Informality as structure or agency? Exploring shed housing in the UK as informal practice. International Journal of Urban and Regional Research 43(3): 569-575.

Lux M and Mikeszova M (2012) Property restitution and private rental housing in transition: The case of the Czech Republic. Housing Studies 27(1): 77-96.

Marx C and Kelling E (2019) Knowing urban informalities. Urban Studies 56(3): 494-509. 
McFarlane C (2012) Rethinking informality: Politics, crisis, and the city. Planning Theory \& Practice 13(1): 89-108.

McFarlane C and Waibel M (2016) Introduction: The informal-formal divide in context. In: McFarlane C and Waibel M (eds) Urban informalities. London: Routledge, pp. 15-26.

Misztal B (2002) Informality: Social theory and contemporary practice. London: Routledge.

Mojanchevska K (2020) Governing diversity in socially fragmented urban settings: 'Skopje 2014' and the ethnocratic homogenization of public spaces. Urban Research \& Practice 13(4): 452-464.

Morris J and Polese A (eds) (2013) The informal post-socialist economy: Embedded practices and livelihoods. Routledge.

Miłosz C (1953) Zniewolony umyst. Paryż: Instytut Literacki.

Müller M (2020) In search of the global east: Thinking between north and south. Geopolitics 25(3): 734-755.

Müller M (2021) Footnote Urbanism. In: Lancione M and McFarlane C (eds) Global Urbanism: Knowledge, Power and the City. London: Routledge, pp. 88-95.

Müller M (2021b) Worlding geography: From linguistic privilege to decolonial anywheres. Progress in Human Geography 0309132520979356.

Odendaal N (2012) Reality check: Planning education in the African urban century. Cities 29(3): 174-182.

Payne G, Durand-Lasserve A and Rakodi C (2009) The limits of land titling and home ownership. Environment and urbanization 21(2): 443-462.

Pieterse DE (2013) City futures: Confronting the crisis of urban development. London: Zed Books Ltd..

Polese A, Morris J and Kovács B (2016) "States" of informality in post-socialist Europe (and beyond). Journal of Contemporary Central and Eastern Europe 24(3): 181-190

Polese A, Morris J, Kovács B and Harboe I (2014) 'Welfare states' and social policies in Eastern Europe and the former USSR: where informality fits in?. Journal of Contemporary European Studies 22(2): 184-198.

Polese A and Rekhviashvili L (2017) Introduction: Informality and power in the South Caucasus. Caucasus Survey 5(1): 1-10. 
Polese A, Rekhviashvili L and Morris J (2016) Informal governance in urban spaces: Power, negotiation and resistance among Georgian street vendors. Geography Research Forum 36(2): 15-32.

Potts D (2020) Broken Cities: Inside the Global Housing Crisis. Zed Books Ltd..

Rekhviashvili L (2015) Marketization and the public-private divide: Contestations between the state and the petty traders over the access to public space in Tbilisi. International Journal of Sociology and Social Policy 35(7/8): 478-496.

Rekhviashvili L and Sgibnev W (2018) Placing transport workers on the agenda: the conflicting logics of governing mobility on Bishkek's Marshrutkas. Antipode 50(5): 13761395 .

Robinson J (2008) Developing ordinary cities: city visioning processes in Durban and Johannesburg. Environment and Planning A 40(1): 74-87.

Robinson J (2013) Ordinary cities: between modernity and development. London/New York: Routledge.

Robinson J (2016) Thinking cities through elsewhere: Comparative tactics for a more global urban studies. Progress in Human Geography 40(1), 3-29.

Robinson J (2016b) Starting from anywhere, making connections: globalizing urban theory. Eurasian Geography and Economics, 57(4-5), 643-657.

Rogerson CM (2016) Progressive rhetoric, ambiguous policy pathways: Street trading in inner-city Johannesburg, South Africa. Local Economy 31(1-2): 204-218.

Roy A (2005) Urban informality: Toward an epistemology of planning. Journal of the American Planning Association, 71(2), 147-158.

Roy A (2009) The 21st-century metropolis: new geographies of theory. Regional Studies 43(6): 819-830.

Roy A and AlSayyad N (eds) (2004) Urban informality: Transnational perspectives from the middle East, Latin America, and south Asia. Lanham: Lexington Books.

Salukvadze J and Golubchikov O (2016) City as a geopolitics: Tbilisi, Georgia - a globalizing metropolis in a turbulent region. Cities 52: 39-54. 
Sayın Ö, Hoyler M and Harrison J (2020) Doing comparative urbanism differently: Conjunctural cities and the stress-testing of urban theory. Urban Studies 0042098020957499.

Sgibnev W (2015) Remont: housing adaptation as meaningful practice of space production in post-Soviet Tajikistan. Europa Regional (1-2): 53-64

Sihlongonyane M (2015) The rhetorical devices for marketing and branding Johannesburg as a city: a critical review. Environment and Planning A 47(10): 2134-2152

Simone A (2004) People as infrastructure: Intersecting fragments in Johannesburg. Public Culture 16(3): 407-429.

Sheppard E, Leitner H and Maringanti A (2013) Provincializing global urbanism: A manifesto. Urban Geography 34(7): 893-900.

Shokalo M (2011) 'Buy from babushkas': Markets in Ukraine, BBC Ukrainian

Service, 7 March 11, http://news.bbc.co.uk/1/hi/programmes/direct/ukraine/9409814.stm (accessed 25.09.2020)

Stanek $Ł$ (2020) Architecture in global socialism: Eastern Europe, West Africa, and the Middle East in the Cold war. Princeton University Press.

Stenning A and Hörschelmann K (2008) History, geography and difference in the postsocialist world: or, do we still need post-socialism?. Antipode 40(2): 312-335.

Sýkora L and Bouzarovski S (2012) Multiple transformations: Conceptualising the postcommunist urban transition. Urban Studies 49(1): 43-60.

Tammaru T, Van Ham M, Marcińczak S and Musterd S (eds) (2015) Socio-economic segregation in European capital cities: East meets West. Abingdon: Routledge.

Temelová J, Novák J, Ouředníček M and Puldová P (2011) Housing estates in the Czech Republic after socialism: various trajectories and inner differentiation. Urban Studies 48(9): 1811-1834.

Thieme TA (2018) The hustle economy: Informality, uncertainty and the geographies of getting by. Progress in Human Geography 42(4): 529-548.

Tsenkova S (2009) Self-made cities: In search of sustainable solutions for informal settlements in the United Nations economic commission for Europe region. New York \& Geneva: United Nations Publications. 
Tsenkova S (2014) Planning trajectories in post-socialist cities: patterns of divergence and change. Urban Research \& Practice 7(3): 278-301.

Trubina E, Gogishvili D, Imhof N and Müller M (2020) A part of the world or apart from the world? The postsocialist Global East in the geopolitics of knowledge. Eurasian Geography and Economics, 1-27.

Turner JF (1977) Housing by People: Towards Autonomy in Building Environments. New York: Pantheon Books.

Tuvikene T (2016) Strategies for comparative urbanism: post-socialism as a de-territorialized concept. International Journal of Urban and Regional Research 40(1): 132-146.

Varley A (2013) Postcolonialising informality?. Environment and Planning D: Society and Space 31(1): 4-22.

Venkov N (2018) Assembling the post-socialist marketplace: transitions and regeneration projects at the central pazar of Sofia. EthnoAnthropoZoom/ЕтноАнтропо3ум, 17, 229-279.

Warzywoda-Kruszyńska W and Jankowski B (2013) Ciagłość i zmiana w łódzkich enklawach biedy. Łódź: Wydawnictwo Uniwersytetu Łódzkiego.

Watson V (2009) Seeing from the South: Refocusing urban planning on the globe's central urban issues. Urban Studies 46(11): 2259-2275.

Watson V (2014) African urban fantasies: dreams or nightmares? Environment and Urbanization 26(1): 215-231.

Wiest K (2012) Comparative debates in post-socialist urban studies. Urban Geography 33(6): 829-849.

Young C and Kaczmarek S (2008) The socialist past and post-socialist urban identity in Central and Eastern Europe: the case of Łódź, Poland. European Urban and Regional Studies, 15: $53-70$.

Yiftachel O (2006) Essay: Re-engaging planning theory? Towards 'South-Eastern' perspectives. Planning Theory 5(3): 211-222

Zhao Y (2020) Jiehebu or suburb? Towards a translational turn in urban studies. Cambridge Journal of Regions, Economy and Society 13(3): 527-542.

Zysiak A (2014) The desire for fullness. The fantasmatic logic of modernization discourses in the turn of the $19^{\text {th }}$ and 20th century in Łódź. Praktyka Teoretyczna 13: 41-69. 


\begin{abstract}
${ }^{\mathrm{i}}$ For the ease of the argument the terms North and South will be referred to in the paper. However, I acknowledge the diversities and contradictions embedded in these formulations and treat them more as epistemic constructs rather than any real 'geographic' denominator. Similar apples to the 'post-socialist' cities - the term, that has been heavily contested by now and the 'Global East', that is not uniformly accepted as an alternative. I will use these interchangeably either referring to past or newer discourses. This acknowledges that these denominators are applied to cities, which might share some historical experiences but often are very diversified. ii The term 'post-socialist Global East' is already in use.
\end{abstract}

